\title{
The Ottawa Roman Catholic Separate School Board's Artists-in-Residence Program (1970-1988): One Point of View
}

\author{
Richard Lachapelle, Concordia University \\ richard.lachapelle@concordia.ca
}

\begin{abstract}
This paper documents an educational artist-in-residence program that was particularly active in some Ottawa Roman Catholic Separate School Board primary schools during the period 1970 to 1988 . In schools where space was available, professional artists were assigned studio space as a means to encourage their participation in the day-to-day life of the schools. In exchange, the visual and performing artists offered non-teaching services that included mentoring and participation in stage plays, mural creation and art exhibitions. These activities mainly took place within the framework of the artists' everyday ongoing professional practice.
\end{abstract}

Keywords: Artists-in-residence; Artists-in-the-schools; Educational Modeling; Demystification of the Arts; Valorization of the Arts

$\mathrm{T}$ This paper documents a rather unique educational artist-in-residence program that took place in some Ottawa Roman Catholic Separate School Board (OSSB) primary schools starting in the early 1970s. The program in question was particularly active during the period 1970 to 1988 , and this article focuses mainly on events that took place during that eighteen-year period. Furthermore, the paper unapologetically presents the program's key events as retold from the point of view of the program's main instigator, Greg Conway. Therefore, readers should bear in mind that other participants in the development of this program might not necessarily agree with the perspective presented in this account. Nonetheless, the uniqueness of this program calls for its documentation as a means to preserve a record of this undertaking whose significance, both in educational and historical terms, still remains to be determined and, perhaps, fully appreciated.

In brief, the Ottawa Roman Catholic Separate School Board (OSSB) Artist-inResidence Program provided professional artists with studios in schools where space was available as a means to encourage artists to become involved in the day-to-day life of the schools. In exchange for studio space, the visual and performing artists offered the schools, the students and, in some cases, the students' parents with art services, mentoring, and creative opportunities such as, for example, participation as production assistants in preparing stage productions and art exhibitions. All these activities took place within the framework of the artists' everyday ongoing professional practice. This Artist-in-Residence program was founded on the idea of the "principle of educational-modeling" where learning is understood to be in part the product of "on-going contact" among students, teachers, and community members - in this case, artists (Conway, 1978b, p. 4). "The 
Artist-in Residence idea is an old idea, in terms of universities and colleges of postsecondary learning. The idea of an Artist-in-Residence in an elementary or secondary school is unusual. As a form of extension programming, the Ottawa Roman Catholic Separate School System is pioneering the Artist-in-Residence Program in this area" (Conway, 1978b, p. 4).

\section{The Literature on Artists in the Schools}

The research literature on artists-in-residence and artists-in-the-schools programs focuses principally on two areas of concern. First, a number of publications present argumentations in favor of such projects or document case studies of specific projects to be considered as exemplars for emulation (Niebur, 1992; Bresler et al., 2000; Sallis, 2009). These texts sometimes offer advice on how to establish artists-in-residence programs in schools where none already exist (Silverstein, 2009). Second, a lesser number of articles present carefully constructed critiques of artists-in-residence programs. These publications address both their strengths and weaknesses in terms of educational value and, at times, advise caution and restraint in their implementation, and identify aspects of such programs requiring improvement (Dimondstein, 1976; Lehman, 1992; Hanley, 2003; Kind et al., 2007).

In relation to the second concern, Kind and colleagues (2007) write about a threeyear pilot artist-in-residence program that took place in the lower mainland of British Columbia with financial support from the Royal Conservatory of Music (Toronto, Canada). The field for the research activities was three of seven primary schools participating in the B.C. component of the project. In these three schools, the researchers examined how the artist-in-residence program addressed the stated goal of providing professional development to primary school teachers. To this end, they studied interactions among artists and teachers, aspects of mutual learning, as well as the project's prospects for professional development for both the artists and teachers (pp. 840-841). As a result of their study, the researchers identified clear "tensions and challenges" related to participation in the program and a "need to open spaces for artists to construct new understandings of themselves as teachers in relation to themselves as artists, and for teachers to develop artist selves alongside their teacher selves" (p. 839).

Hanley (2003) also writes about the Royal Conservatory of Music's Learning Through the Arts program and, as well, a similar program called ArtSmarts (a partnership of the Calgary Arts Partners in Education Society and the J. W. McConnell Foundation of Montreal). Both programs provide funding for educational projects that place artists as resource persons in the schools for periods of varied duration. Hanley begins by acknowledging the positive contribution of these programs.

Artists-in-the-schools tend to bring novelty and generate excitement in schools. Artists working in elementary school settings certainly share their passion and expertise with students and teachers and, often, with the greater community. The community spin-offs are particularly important in smaller, rural communities. (p. 12)

However, Hanley is very critical of some of the less positive impacts of such programs. In some schools, these temporary programs have "displaced" the specialist art teacher and have resulted in the "depreciation of arts educators," a "devaluation" and a denigration of teaching (pp. 13-14). Furthermore, artists-in-the-schools programs tend to be conducted on a short term "drop-in basis", and they often focus on a specific outcome 
of short duration: a performance or an exhibition (p. 14). Often, artists-in-the-schools programs fail "to achieve curriculum outcomes in the arts" (p. 15) and do not make the essential distinction between "arts experiences" and "arts education" (p. 18). Finally, Hansen concludes by expressing concern about the future of arts education in these schools once the program funding runs out.

Concerns such as those expressed by Hanley do not necessarily apply to the OSSB Artist-in-Residence Program that is the focus of this paper. First, the artists participating in the OSSB Program between 1970 and 1988 were not remunerated. Second, artists were not expected to assume a teaching role in the schools where they were assigned studio space as artists-in-residence. These schools still had in-house or visiting arts specialist teachers to instruct the Ontario arts curriculum. In sum, the conditions under which the OSSB program functioned were quite different from the circumstances dictated by present-day, charitable foundation or government sponsored, artists-in-the-schools and artists-inresidence programs.

Nonetheless, widely established governmental policies promoted the involvement of artists in schools and certainly paved the way for an eventual full-time OSSB Artist-inResidence Program. From a present-day perspective, many of the events that shaped the development of the OSSB Artist-in-Residence Program might seem a little astonishing. That a program like the OSSB Program came into existence in the early 1970s was certainly due, in a significant way, to the social, political and economic climate of the times. At the time, the fiscal philosophies and actions of Canadian federal, provincial, and municipal governments and their respective cultural and educational institutions (including local school boards) differed greatly from those of present-day governments. Today, the governmental fiscal climate is largely shaped by an ongoing struggle to regain control over escalating budgetary deficits. However, informed by Keynesian economic principles during the period 1950 to 1980, the Canadian government pursued "both a stimulative monetary policy and an expansionary fiscal policy" in order to soften the effect of rising oil prices and "at the same time to stabilize the economy" (Makarenko, 2009). Deficit financing was seen in mostly positive terms as a tool for managing and stimulating the economy in order to maintain high levels of employment.

During the same period, as part of this focus on employment, governmental agencies developed a keen interest in the economic and educational potential of artists working in the schools. As a result, provincial and territorial institutions in the cultural sector adopted policies and created funding programs to encourage greater integration of professional artists within the educational system. These programs were designed to meet two complementary objectives: first, by encouraging the involvement of artists in the schools, arts councils were seeking to expand art education within schools by funding activities understood to complement existing art education programs; second, the income provided to artists as short-term salaries for their work as resource persons in the schools was seen as an alternative, as well as a supplement, to the usual funding provided to artists through grant programs.

By 1988, a majority of Canadian provinces and territories had some kind of funding program intended to support the participation of artists as education resource persons in schools, libraries, or communities. While the federal Canada Council's mandate, at the time in question (1970-1988), comprised among others an educational role, the Canada Council educational programming did not include a national artist-in residence program 
(Lachapelle, 1988f; McCaughey, 1988). At the provincial level, the Ontario Arts Council (program founded in 1973) and the Manitoba Arts Council (program founded in 1976) operated the two most extensive programs. After six years in operation, the Manitoba Arts Council's Artists in the Schools Program was formally evaluated in 1982 and this review determined that the program answered the needs of the schools participating in the program. Certain disciplines were favored over others by Manitoba schools: most requests for funding from the program were for activities involving music, followed by theatre arts and dance (Chapman, 1982).

Like the Manitoba Arts Council's program, the Ontario Arts Council's Creative Artists in the Schools Program provided funding on a cost-shared basis to schools who wished to have a professional artist come to their school for a period of time ranging from a few days to two weeks. Under the aegis of this program, artists normally undertook special creative activities with all or part of the students in the school they were visiting (McCaughey, 1988).

Alberta and New Brunswick both had programs that were initially established in 1975. Alberta's program was aimed at all levels including primary, secondary and postsecondary educational institutions and the community at large. Alberta's program however applied only to two disciplines: the performing arts, and film and literary arts (Lachapelle, 1988b). New Brunswick had an Artist-in-Residence program in music and writing targeted to universities with a writers-in-residence component aimed at libraries (Lachapelle, 1988e).

British Columbia's Artists in School Program was created in 1980. The program had two aspects. The first was an Artist-in-Performance component whereby musicians performed in a school and then stayed on for a few days to conduct workshops or similar activities. The second consisted of an Artist-in-Residence component that allowed for the establishment of a residency in a school lasting anywhere from 3 days to 4 months. Both of these components were made available to grades Kindergarten to twelve (Government of British Columbia, 1979).

Saskatchewan's program was unique in that it had a broad community base as one of its defining principles. Rather than being placed in schools, Saskatchewan artists were sponsored by senior provincial cultural organizations and placed in a community for 12 months. The artist was expected to allocate $50 \%$ of his or her time to the community, possibly including schools, and spend the remaining time on his or her own creative work (Lachapelle, 1988g).

The Northwest Territories and the Yukon had programs that were established in 1987 and 1988 respectively. The Yukon's program was more limited in scope: it was a Writers-in-Residence program aimed at public libraries. Three residencies a year were available: one for a First Nations' author, one for an author of adult fiction, and a third for a children's author (Lachapelle, 1988d). The Northwest Territories had a wide ranging Artists-in-the-Schools program where artists in all disciplines, both from the N.W.T. and elsewhere, could spend time working with students in public or private primary and postsecondary institutions (Lachapelle, 1988a).

Quebec's Ministère des Affaires culturelles also created an artists-in-schools program in 1987. The Sensibilisation auprès des jeunes en milieu scolaire program provided funding, placement and technical support to professional artists and artisans so that they could spend time in primary or secondary schools (public and private) conducting 
activities aimed at developing an appreciation of the arts. Participation in the program was open to artists in all aspects of the visual and performing arts (Lachapelle, 1988h).

Finally, the Prince Edward Island Council of the Arts operated an artist-inresidence program during the period 1979 to 1987 . This unique program had three components: a regular Artist-in-Residency section, a Folk Artists in the Schools section, and a Short Term Workshop/Performance section. The program was run in large part on funds acquired from federal work creation programs like the "Canada Works" program. When the Council was unable to secure funding for the program in 1987, it folded (Lachapelle, 1988c).

In sum, due to the Canadian fiscal and public funding policies that started in the second half of the $20^{\text {th }}$ Century, as well as to the overall cultural and educational climate at the time that included several provincial and territorial "artists in the schools" funding programs, the stage was set for the eventual development of a bold initiative like the Ottawa Roman Catholic Separate School Board's (OSSB) Artist-in-Residence Program. Such a program likely appeared feasible to OSSB decision makers since, at the time, artists from all disciplines were becoming much more involved in the overall school system.

\section{Method}

The research conducted in preparation for this publication was informed by a qualitative historical case study method. I collected the data using two procedures: in-depth interviewing and archival research. First, I interviewed Greg Conway who was, at the time, Coordinator of Related Arts at the School Board and instigator of the Artist-in-Residence Program; I met with him at his office in the Ottawa R. C. Separate School Board's headquarters in Ottawa ${ }^{i}$. Using a semi-structured interview outline, I questioned Greg Conway extensively on his recollection of the key events that shaped the creation and ongoing development of the Artist-in Residence program between the years 1970 and 1988. Then, with his permission and the assistance of OSSB staff members, I examined all current files as well as the archival documents available at the Board headquarters related to the program. In this second phase of data collection, I used available documents to corroborate and, sometimes, correct dates and details of events as previously told to me by the interviewee. I also found some new materials and subsequently discussed these with my participant, carefully documenting his answers about them in my written research notes. Finally, I produced a first draft of a research paper. In order to conduct a participant review, I provided a copy of this initial draft to my interviewee and asked him to carefully appraise the document in order to identify any changes that might be required. To this end, Greg Conway proposed five corrections, all of which were included and preserved in all subsequent revisions of the manuscript (G. Conway, personal communication, January 2, 1989).

\section{To Begin: A Personal Formative Experience}

To initiate the conversation that unfolded during the formal interview that I conducted with Greg Conway, I asked him first where he first got the idea of a school based artist-in-residence program. I also asked him about his initial motivations for trying to implement an artist-in-residence program within his own School Board. I had expected an administrative answer, something to do with the recent availability of resources or some other similar organizational reason, but Greg Conway surprised me with a rather personal account of a childhood formative experience. 
Well, the very first motivation, the principle motivation, has been the fact that, as a child growing up in a rural community in the upper part of the Ottawa Valley, my greatest opportunities - as time has proven-were those opportunities that came about by chance. When I was a kid, I remember being on my grandmother's farm and seeing one morning, very early, someone who was, it became very obvious that he was painting way up on what we called the "old sheep pasture". And, curiosity got the better of me, and what I did was that I finally pumped the real old well ... [put] some ice cold water into a little tin honey pail and carted it up and asked him if he wanted a drink. The guy was A. Y. Jackson! And, that started a relationship with the Group of Seven and it was from that I then picked up an awful lot of enriching experience and an enriching interest in art. However, to get to my point, I always believed ever after, still do, that the only way I could ever repay my good fortune...was to try and make those happy accidents available to as many other people as I could. One way of doing that was to put artists right into the schools, not as teachers, but as I found A. Y. Jackson in the old sheep pasture, an artist (Conway, 1988).

\section{The Demographic Context of the late 1960s}

Contrary to the early 1960s when the Ottawa Separate School Board's student population burgeoned to an all time high, the year 1969-1970 marked the beginning of a very significant decline in enrollment. The number of schools operated by the Board and the number of students enrolled started to drop from a high of over 32,000 pupils in a total of 110 schools to a 1988 level of just 15,000 students spread out over 50 schools (Conway, 1988).

Initially, this reduction in student population did not affect any single specific geographic area within the School Board's jurisdiction and, therefore, it did not result in any empty schools that had to be closed. Rather, the decline was quite generalized. Almost all schools experienced a drop in student enrollment. As a consequence, many if not most of the schools ended up with one or more empty classrooms. Greg Conway saw this turn of events as an opportunity to create new programs that would make use of these recently vacated spaces, now sitting empty, and perhaps available for new purposes within his Board's schools.

\section{The Heron Road Pilot Project}

From 1964 to 1970, Greg Conway had been in charge of the Ottawa Separate School Board's Art Department, which initially coordinated the art program for the English Sector of the Board and then, starting in 1965, for both the English and French Sectors ${ }^{\text {ii }}$. In 1970, the administrative structures and positions in the Board were revised, and he became Coordinator of Related Arts (Art, Music, Dance and Drama) solely for the English Sector of the Board.

In 1970, Greg Conway decided to seek permission to set up a one year experimental Artist-in-Residence Program. Conway obtained the clearance required to present his proposal to the School Board. The Board's Trustees, as the elected representatives of the taxpayers, are the ultimate authority within any school board and, as such, have the authority to support new innovative projects. Prior to presenting his case to the Board, Greg Conway applied to the Ontario Arts Council for a grant in order to finance fifty percent of the cost of the pilot project. Upon presenting his plan to the OSSB Board at one of its 
regular meetings, Mr. Conway realized that support for his Artist-in-Residence idea was, at best, lukewarm. Conway credits Pierre Mercier, the Chairman of the Board at the time, with rescuing his apparently doomed project. Mercier's enthusiastic and strong support for the plan had a dramatic outcome: Mercier not only managed to convince his fellow Board members that they should support this project, but also that they should commit themselves to financing its entire cost ${ }^{\mathrm{iii}}$ should the hoped-for funding from the Ontario Arts Council not materialize. This is what eventually transpired, as the Arts Council eventually rejected Conway's grant application (Conway, 1988).

The Heron Road Pilot Project involved a total of three English-language schools all located within close proximity to each other on Heron Road in Ottawa. Saint-Patrick/Notre Dame High School was a combined co-educational secondary school (grades 9 to 13) with a total population of about 1,100 students. Heron Road Intermediate School (grades 7 and 8) had a population of about 700 students. Finally, Queen of the Angels Elementary School served a population of about 300 students in grades K (Kindergarten) to six. Greg Conway chose these schools for the pilot project because he felt that, with the combined enrollment of these three schools, he had a representative population: a total of 2,000 students, aged from 5 to 18 years, enrolled in grades $\mathrm{K}$ to 13 . The proximity of each school in relation to the others resulted in a convenient cluster of sites in which to undertake a pilot project.

Out of a need for expediency, Greg Conway recruited artists from the Toronto art scene, with which he was more familiar at the time. Artists were chosen according to the need for a representative cross-section of various artistic disciplines, as well as according to the ability of each individual artist to create a real impact and work effectively in the schools to which they were assigned as artists-in-residence. A total of eight artists were selected for the project: 2 musicians and 6 visual artists working in various media. The musicians were Bobby Gimby —well known at the time as Canada's 1967 "Centennial Pied Piper" - and Pat Riccio, a tenor saxophone player and a big band jazz musician of note. Representing the visual arts were Hugh McKenzie (a portrait painter known for his work in egg tempera), Garth Haines (a designer, best known for his design of the Steel Pavilion at Expo 67 in Montreal), Mike Smitherman (a graphic designer), Gerry Lazarre (an instructor in painting and illustration at the Ontario College of Art), Lewis Parker (an historical illustrator who, along with Gerry Lazarre, realized the critically acclaimed diorama murals for the mammal display at the National Museum of Natural Sciences in Ottawa), and Richard Nevitt (an instructor at the Ontario College of Art and an artist specializing in pen and ink, and anatomy).

All of these eight artists came to Ottawa at some point during that year (1970) to spend two to three successive days at Heron Road Intermediate School, where available space had made it possible to set up studios for the exclusive use of the visiting artists. Each artist was paid a daily honorarium ${ }^{\text {iv }}$. Even though the artists' studios were located in Heron Road Intermediate School, all the students and teachers from the three schools in the area had the opportunity to meet and interact with the visiting artists, if they so wished.

By the end of the year, the project was deemed a success. Early on in the pilot project, teachers, students and parents began to provide spontaneous, informal, and positive feedback about the experiment. Later, these early comments and impressions were corroborated by the results of a survey conducted by Greg Conway's office. A questionnaire was sent to all the children and their parents as well as to all teachers and personnel of the three schools. The response to this survey must have been very gratifying 
for the members of the Related Arts Office. The rate of return for the questionnaire was over $65 \%$, an unusually high number for any survey. From this large number of responses, only one comment was said to be negative! Parents, teachers and students had given their overwhelming approval to this new educational idea of a visiting artists-in-residence program (Conway, 1988).

\section{The St-Elizabeth School Experiment}

Understandably elated by the success of the Heron Road project, Greg Conway recommended one more project to the School Board. In 1971, St-Elizabeth School, which was located in the West-End of the city, was chosen as the site for a modified version of the previous year's experiment. This school was selected mainly for the particular character of its student population, which was culturally diverse and in many other ways pluralistic. St-Elizabeth students came from a wide variety of backgrounds. There were recent immigrants as well as long established local families. Some students came from poor families while others had more affluent backgrounds. Furthermore, this school's population included a wide spectrum of different ethnic groups.

As for the artists taking part in this second project, some changes were also introduced. While half of the visual artists from Toronto were brought back to Ottawa for the second trial, a complement of local Ottawa artists was also added. This time, the Related Arts officers sought out artists that they did not know, and rather than select more painters and sculptors, they chose to bring in some professional artisans. Two examples that illustrate the caliber of crafts people that were selected for the program included Rosemary Schein, a goldsmith, and Ann Orton, a weaver. Other artisans who participated in the project were, like Schein and Orton, associated with an artists' collective which operated under the name "521/2 George"v.

This second experiment was also a tremendous success. The artists, once more, became very involved in the life of the school. Projects undertaken by the artists with the students were varied and included sketching trips, discussion groups on the artists' work, and on the topic of the art making process. Good communication between artists, teachers, students and parents was said to have been an important factor in the positive outcome of this second trial (Conway, 1988).

\section{Establishment of a permanent Artist-in-Residence Program}

With the success of this second experiment, the creation of a permanent program was within reach. In late 1971, the Ottawa Separate School Board gave its final approval for the creation of an ongoing permanent Artist-in-Residence Program. Initially, the parameters of the program were quite simple. Where there was space available in a school, an artist-in-residency could be established. Greg Conway, as the Coordinator of Related Arts Education, was to manage the program by matching up artists with available spaces.

In exchange for unlimited access to the studio space-artists were given keys to the school buildings so that they could use the space at all times - artists agreed to comply with three basic conditions. The first of these conditions was that they occupy the space for a minimum of two school days per week. Second, artists were to make themselves available to students and teachers for "possible participatory activity in the arts and as a resource in the arts". Finally, artists were asked to preserve their "identity as artists" by not engaging in "a formal teaching program" (Conway, 1978a). 
By 1979, eight years after being first established, the Program included a total of 36 artists in 16 different schools (Conway, 1979). For the most part, artists-in-residence were individual artists working alone, but in some cases artists chose to share studios with other artists with similar creative interests. In other cases, residencies were also granted to theatre and dance companies. Individual artists-in-residence included filmmakers, photographers, painters, sculptors, printmakers, potters, weavers, and artisans.

In a report dated 1978 on the activities of the program, Greg Conway lists the following accomplishments:

1) "In addition to the usual studios, the Artist-in-Residence Program has also been responsible for the development, and maintenance of a 65 -seat professional, pocket-theatre at Canadian Martyrs School, a Community Art Gallery at Saint-Georges School and several photographic darkrooms. Furthermore, the Artist-in-Residence Program has been responsible for the 90 square foot mural at St. Elizabeth School, the new mural underway for St. Leo's, the 'electronic/plexiglas' mural being developed at Corpus Christi and numerous art pieces and theatre productions constantly enhancing our schools' environment" (Conway, 1978b).

2) "The students and staff have access to the Artists' studios, enabling them to become acquainted with the artists and the nature of their work. Activities generated from this contact include children and staff involved in stage design, playwriting and scripting, building of stage sets, black-1ight theatre presentation, an artist/apprentice program, photography and film, the construction and operation of an art gallery and experience with numerous materials [and] procedures: raku firing, vacuum-form sculpture, plaster casting, electronic sculpture, mural painting and assemblage, to name only a few" (Conway, 1978b).

\section{Expansion to the French Sector of the Board}

Up until 1977, the activities of the Artist-in-Residence Program had been limited to the English Language schools for which Greg Conway was responsible as the Coordinator of Related Arts Education. In 1977, as a result of lobbying on the part of French-speaking artists ${ }^{\mathrm{vi}}$, the Program was expanded to the French Sector of the Ottawa Separate School Board. Initially, Jean-Claude Dorval, Conway's homologue in the French Sector, administered the Artist-in-Residence program in the French division of the OSSB Board. Later, the French program was coordinated in turn by Yves Sincennes, and eventually by Richard Landry who still ran the program in 1988 (Conway, 1988).

\section{The Second Space Pocket-Theatre Project}

Starting in 1976, Canadian Martyrs School on Graham Avenue became the focal point of some very interesting Artists-in-Residence Program developments in the area of theatre arts. Early in 1976, Don Bouzek, a recent graduate in theatre from University of Alberta's Master of Fine Arts Program, approached Greg Conway with a request for studio space for his fledgling Penguin Theatre Company. The company was given artist-inresidence status at Canadian Martyrs School along with space for the Company's activities in the basement of the school building (Shaw, 1980).

The residency conditions were less than ideal; the theatre company-in-residence worked out of a basement with no real stage or other performance space in which to present their productions. Nonetheless, Penguin Theatre managed in its first year of operation to 
produce eight plays, four of which were Canadian original creations and one a Canadian Martyrs School student production (Penguin Theatre, 1979).

No doubt impressed by the vitality of this young theatre company, Conway began to conceive, along with Bouzek, plans to renovate the basement of Canadian Martyrs school to better accommodate the needs of Penguin and other small theatre companies in Ottawa.

The renovation project for the building was quite ambitious. Initially, plans were to knock down a wall at the back of the school, construct an addition to the building that could be used both as a gymnasium and a theatre. The end wall of the gymnasium was to be designed in such a way that it could be raised or pulled back, so that the stage could form part of a second, outdoor amphitheater for summer time use. Furthermore, skylights were to be added to the building so as to provide natural lighting for studio space in the basement of the building. This proposal, along with an estimate of its cost $(\$ 340,000)$ was put to the executive of the OSSB who, by now had a new Director of Education, Berchmans Kipp. Part of the proposal presented that day was that capital funding for the project was to be secured from external government sources through grant applications. Understandably, Director Kipp and the other OSSB executives were not convinced that grants could be secured for such a project. Notwithstanding, Mr. Kipp gave permission for an attempt to secure funding for a scaled-down project that would not involve any structural changes to the school building. Later that same morning, Greg Conway was on his way to Toronto, Ontario's provincial capital, in a bid to secure the $\$ 42,000$ that he now estimated was required to bring to fruition this smaller version of the theatre-house project. Arriving unannounced, Conway presented his project to the Theatre Officer of the Ontario Arts Council. While impressed with the plan, the Theatre Officer could foresee no possibilities of grants for the project, but decided nonetheless to consult with Louis Applebaum, the President of the Arts Council. In turn, Applebaum mentioned the idea to Robert Welch, provincial Minister of Recreation and Culture, attending a meeting that same day with Applebaum. Keen on the idea of an educational performance space, Welch personally authorized the capital grant of $\$ 43,000$ required for renovations to Canadian Martyrs School and for purchase of equipment, in order to transform it into a "pocket-size" performing arts facility (Conway, 1988).

Construction was undertaken during the 1977-1978 school year. Renovations involved moving the staff room from the basement to the ground floor, and turning the former staff room into a workshop for set design and construction. One basement classroom was used to create a studio for visual artist Caroline Davis. A second classroom was turned into a studio for Penguin Theatre. A large lunchroom was converted into a 100seat theatre, called Second Space. Initially, the small theatre space was equipped with an improvised theatrical lighting scheme but, in due course, it was replaced by a professional lighting system.

Until the closure of Canadian Martyrs School at the end of the 1982-83 season due to falling student enrollment, the basement of the school was operated as a theatre. Second Space's programming was ongoing, with plays being presented that were produced by Penguin Theatre, as well as other local companies including The Great Canadian Theatre Company, The Projectors of Lagado Theatre Ensemble, and Le Théâtre d'la Corvée.

Students of Canadian Martyrs Schools also used Second Space as a place to write and stage plays. Some children were also given the opportunity to play roles in Penguin 
productions that required child actors. Penguin Theatre also undertook interesting experiments in staging in which older students (grades 7 and 8) played the roles of critics, and thus provided feedback to the company on its productions intended for school audiences. Examples of this type of cooperation between student-critics and professional actors include Landscape, a play on the work of the Group of Seven, presented by Penguin Theatre to student groups from May 12 to 22, 1977, and Alice Through the Looking Glass, a play by Jim DeFelice, produced in 1976 (DeFelice, 1976; Conway, 1988).

\section{An Official Artists-in-Residence Policy (1983)}

Nineteen-eighty-three (1983) marks the year of the passing of an OSSB Board Resolution creating an official Artists-in-Residence Program Policy. Up until that time, the Program was run in an informal fashion based more or less on a tacit understanding among all those involved. Artists came to an individual agreement with the appropriate art coordinator in the English or French Sector as to the nature and conditions of their residency as participants in the Program. However, in 1983, the OSSB Resolution titled "Policy B-6: Artists-in-Residence Programme" was adopted in part to reassert the Ottawa Separate School Board's commitment to the Program and, also, to ensure the continuation of the program when coordinators of the program were on leave. The policy did, however, set conditions and restrictions on the operations of the program that, before, did not exist. For example, the policy restricted the artists' access to the schools to certain hours on "instructional days" (08:00 to 22:00 hours) and on "non-instructional days" (09:00 to 17:00 hours). Additionally, the initiative and responsibility for establishing and maintaining an artist-in-residence in a school was taken away from the Related Arts Office and granted instead to the individual principals of the schools involved in the program (Ottawa RomanCatholic Separate School Board, Policy B-6, 1983).

\section{Challenges to the Survival of the Program}

By 1988, seventy-two (72) professional artists and at least twenty-one (21) different schools ${ }^{\text {vii }}$ had participated in the Ottawa Separate School Board's Artists-in-Residence Program (Lachapelle, 1988i). However, two important events with potentially unpredictable effects soon appeared on the horizon as developments that could shape and determine the very future of the Program.

In December 1988, the Ontario Provincial Legislature adopted Bill 109 establishing a new French language school board (comprised of a Catholic and a Public Sector) that was to group and administer all French language schools within the city of Ottawa and parts of the greater Ottawa area (Conseil des écoles catholiques du Centre-Est, 2014). The new board - the Conseil scolaire de langue française d'Ottawa-Carleton-was granted jurisdiction over the French language Catholic schools that were previously owned and operated by the Ottawa Separate School Board's French Sector. At the time, it was uncertain whether the Artists-in-Residence Program would survive in the new French catholic schools. However, there did not appear to be any imminent threat to the Program arising simply out of the establishment of the new French language Board.

In 1988, a more immediate threat to the survival of the Program was the leveling in the decline of student enrollment within the overall separate school system in Ontario. Originally, it was this decline in separate school populations that created the factors that led to the opportunity to set up artists' studios in vacant spaces in the OSSB schools. It was ironic indeed that the return to a more stable level of student enrollment in the OSSB's 
precinct might pose a menace to the very survival of the Artists-in-Residence Program. Half of the OSSB schools had closed since the early 1970s. It was clear, therefore, that any increase in student numbers would have to be absorbed by the surviving schools. Understandably, the Related Arts Education Office was apprehensive about the possibility that, soon, schools might need to evict their artists-in-residence in order to reclaim the very same spaces that, a few years earlier, sat empty until artists occupied them. Unfortunately, one crucial concession that Greg Conway had not succeeded in obtaining from his Board was a resolution requiring that each school have a studio in which to accommodate a resident artist (Conway, 1988).

Indeed, in the years that followed, as greater numbers of students entered the separate school system, some OSSB artists-in-residence were asked to vacate their studios so that these spaces could be reclaimed and used again as bona fide classrooms.

By 1997, however, additional provincial legislation led to a further restructuring of Ontario school boards along with a rationalization of resources and an allotment of school properties based in part on changes in the geographical distribution of specific student populations. In 1998, the Ministry of Education created a total of 72 new school boards (including 12 new French language school boards) to replace the 167 previous boards. This new legislation, Bill 204, dictated the merger of several school boards in order to create fewer, but larger administrative structures. Thus, the Ottawa Roman-Catholic Separate School Board (OSSB) merged with the Carleton Roman Catholic Separate School Board in order to create a new entity: the Ottawa-Carleton Catholic School Board. Given the redistribution of school properties undertaken at this time, we can assume that more OSSB artists-in-residence were asked to vacate their studios during this period of governmentdriven restructuring. Indeed, there is anecdotal evidence to support this assumption (Bouchard, D., personal communication, October 15, 2014), but it remains difficult to assess the effect that these changes had on the artists-in-residence program and the extent to which the program continues to exist in some form or another in the newer school boards $^{\text {viii }}$ (Conseil des écoles catholiques du Centre-Est, 2014; Ottawa-Carleton Catholic School Board, 2006).

It seems appropriate to conclude this article by emphasizing, once again, the ways in which the OSSB Artist-in-Residence Program was unique and different from other similar programs, in existence around the same time, that promoted a role for artists in the school system. First, with the exception of the two initial pilot projects discussed earlier, no money was ever paid to the artists who elected to accept a full-time one-year residency in a school. Rather, as it grew, the OSSB Program developed into a barter-based system, where the artist, in exchange for free studio space, agreed to act as a resource person in the arts. Second, artists-in-residence at the OSSB were discouraged from teaching art to students in the usual sense of the word. Rather, the artist was encouraged to act as a role model and facilitator instead of a teacher. She or he was encouraged to participate in the everyday life of the school and to engage students in the kinds of activities that they would not normally get to do in school: create a mural, write a play, build and manage a gallery, perform in a professional stage production, and so on. Finally, an artist was always placed in residency in a school for a period of one year or more. During this time, the students, teachers and artists got to know each other quite well. They profited from this extended opportunity to become comfortable with each other, and to become part of the same community. In such a context, the social role of the artist was both demystified and 
valorized. First, the social role of the artist was demystified for those students who got to witness and understand what the life of an artist is really like. Second, the role of the artist in society was valorized because, in the positive climate provided by the host school, the artist's unique approach to knowledge creation and problem solving was understood by all to be a worthwhile and important social contribution.

\section{References}

Bresler, L., DeStefano, L. Feldman, R. \& Garg, S. (2000). Artists-in-Residence in Public Schools: Issues in Curriculum, Integration, Impact. Visual Arts Research, 26(1), 13-29.

Chapman, E. (1982). Artists in the schools program. Education Manitoba, 8(10), 11-12.

Conseil des écoles catholiques du Centre-Est (2014). Historique. L'éducation catholique en langue française : Une victoire, une fierté! Retrieved from www.ecolecatholique.ca/fr/Apercu-Du-Cecce_1

Conway, G. (1977). A Contextual Perspective on the project. Unpublished manuscript, Related Arts Education Office, Ottawa Roman-Catholic Separate School Board, Ottawa, Canada.

Conway, G. (1978a). Program documentation dated November 20, 1978. Unpublished manuscript, Related Arts Education Office, Ottawa Roman-Catholic Separate School Board, Ottawa, Canada.

Conway, G. (1978b). The artist-in-residence program. Unpublished manuscript, Related Arts Education Office, Ottawa Roman-Catholic Separate School Board, Ottawa, Canada.

Conway, G. (1979). Artist-in-residence program report. Unpublished manuscript, Related Arts Education Office, Ottawa Roman-Catholic Separate School Board, Ottawa, Canada.

Conway, G. (1988, October 25). Interview by Lachapelle [tape recording]. OSSB Artistin-Residence Oral History Project, Concordia University, Montreal, Canada.

DeFelice, J. (1976). Alice Through the Looking Glass, Project Proposal. Unpublished manuscript, Penguin Theatre, Ottawa, Canada.

Dimondstein, G. (1976). Currents in the Arts: Conflicts and Contradictions. Art Education, 29(2), 14-16.

Government of British Columbia (1979). Cultural Services Branch: Programs [Monograph]. Vancouver, Canada.

Hanley, B. (2003). The Good, the Bad, and the Ugly-Arts Partnerships in Canadian Elementary Schools. Arts Education Policy Review, 104(6), 11-20. 
Jay Makarenko. (2009, October 13). Federal fiscal policy in Canada: History, operations, and trends in the global recession [Web log post]. Retrieved from http:// http://mapleleafweb.com/features/federal-fiscal-policy-canada-history-operation-andtrends-global-recession\#canadian.php

Kind, S., de Cosson, A., Irwin, R. L. \& Grauer, K. (2007). Artist-teacher partnerships in learning: The in/between spaces of artist-teacher professional development. Canadian Journal of Education, 30(3), 839-864.

Lachapelle, R. (1988a). [Written response to a request for information about artist-in-theschools programs from J. Broda, November 21, 1988. Yellowknife: Government of the Northwest Territories, Culture and Communications]. Unpublished raw data.

Lachapelle, R. (1988b). [Written response to a request for information about artist-in-theschools programs from R. Hood, November 7, 1988. Edmonton, Alberta: Culture and Multiculturalism]. Unpublished raw data.

Lachapelle, R. (1988c). [Written response to a request for information about artist-in-theschools programs from J. MacDonald, November 14, 1988. Charlottetown: Prince Edward Island Council of the Arts]. Unpublished raw data.

Lachapelle, R. (1988d). [Written response to a request for information about artist-in-theschools programs from M. McTiernan, November 16, 1988. Yukon Education: Libraries and Archives Branch]. Unpublished raw data.

Lachapelle, R. (1988e). [Written response to a request for information about artist-in-theschools programs from J. Saunders, no date. Frederiction, New Brunswick: Tourism, Recreation and Heritage]. Unpublished raw data.

Lachapelle, R. (1988f). [Written response to a request for information about artist-in-theschools programs from D. Sigurdson, November 17, 1988. Ottawa, Ontario: The Canada Council]. Unpublished raw data.

Lachapelle, R. (1988g). [Written response to a request for information about artist-in-theschools programs from V. Thomasson, November 23, 1988. Regina, Saskatchewan: Parks, Recreation and Culture]. Unpublished raw data.

Lachapelle, R. (1988h). [Written response to a request for information about artist-in-theschools programs from F. Levesque, December 13, 1988. Quebec, Quebec: Ministère des Affaires culturelles]. Unpublished raw data.

Lachapelle, R. (1988i). [Compilation of participating artists and schools based on archival documentation up to the end of 1988]. Unpublished raw data.

Lehman, P. R. (1992). Counterpoint. Music Educators Journal, 79(1), 41. 
McCaughey, C. (1988). Arts Education in Canada: An Exploratory Study. Ottawa: The Canada Council.

Niebur, L. (1992). Bringing Artists into the Classroom. Music Educators Journal, 79(1), 40-43.

Ottawa Roman-Catholic Separate School Board (1983). Artist-in-Residence Programme Policy B-6. Ottawa: Ottawa Roman-Catholic Separate School Board.

Ottawa-Carleton Catholic School Board (2006). History of the Ottawa-Carleton Catholic School Board. Retrieved from www.ocsb.ca/images/recordsmanagement/oc-schoolshistorical document.pdf

Penguin Theatre (1979). Penguin chronology. [Monograph].

Sallis, R. (2009). Working Conditions For Teaching and Learning in Drama. Melbourne, Australia: Drama Australia.

Shaw, P. (1980, January 24-30). The Penguin Resignations. Ottawa Revue, no pagination.

Silverstein, L. B. (2009). Artist Residencies: Evolving Educational Experiences. New York: The John F. Kennedy Center for the Performing Arts.

\footnotetext{
i The interview was conducted on October 25, 1988.

ii Until 1988-89, the Ottawa Separate School Board operated both English and French Catholic Schools. The Board's administrative structure consisted of two distinct components: one Section operated the English-language schools and the other, the French-language Schools. Apart from a few shared programs and some common facilities, the only administrative structures that formally linked the two Sections were its Office of the Director of Education and its elected Board of Trustees.

iii The budget for the pilot project was a total of $\$ 3,000$.

iv The honorarium was $\$ 110.00$ a day.

$\checkmark$ The name of the group refers to the Collective's first studio address.

${ }^{v i}$ I was one of the francophone artists that lobbied for the expansion of the program to the French Sector of the Board.

${ }^{\text {vii }}$ Based on available space, some schools welcomed several artists-in-residence.

viii In preparing this article for publication, the author attempted to verify the current status of the Artist-in-Residence program. However, efforts to contact the new school boards have not produced any clear answers as to the fate of the program after the 1998 restructuring.
} 